Reprinted with permission from: Weed Technology. 1997. 11:734-738.

Published and copyrighted by: Weed Science Society of America, http://www.wssa.net

\title{
Diets of angora goats grazing leafy spurge (Euphorbia esula)-infested rangeland ${ }^{1}$
}

\author{
DONALD R. KIRBY, THOMAS P. HANSON, and CAROLYN HULL SIEG \\ Professor, Animal and Range Science Department, North Dakota State University, Fargo, ND 58105; NW District \\ Director, North Central Research Extension Center, Route 3, Box 174, Minot, ND 58701; and Research Wildlife Bi- \\ ologist, USDA Forest Service, 501 East St. Joseph Street, Rapid City, SD 57701.
}

\begin{abstract}
:
Angora goats have been suggested as biological control agents for leafy spurge, especially in environmentally sensitive or limited access areas. Dietary preferences and dietary nutritive content of herded Angora goats were evaluated over a two-year period in North Dakota. Relative preferences of forages were evaluated by comparing botanical composition of diets as determined by microhistological analysis of fecal samples to forage availability in the field. Leafy spurge and shrubs comprised the largest percentage of goat diets throughout each grazing season. Goats preferred leafy spurge and shrubs at all times and avoided most cool-season grass species. The nutritional requirements of Angora goats nursing kids were met throughout the grazing season. Use of Angora goats is another tool available to land managers to manage leafy spurge infestations in the Northern Plains.
\end{abstract}

\section{Nomenclature:}

Leafy spurge, Euphorbia esula L. \#² EPHES, Angora goat, rangeland.

\section{Additional index words:}

Biological control, EPHES, integrated management, nutrient content, relative preference index.

\footnotetext{
${ }^{1}$ Received for publication April 5, 1996, and in revised form July 30, 1997.

${ }^{2}$ Letters following this symbol are a WSSA-approved computer code from Composite List of Weeds, Revised 1989, Available from WSSA, 810 East 10th Street, Lawrence, KS 66044-8897.
} 


\section{Abbreviations:}

$\mathrm{CP}$, crude protein; IVDMD, in vitro dry matter digestibility; $\mathrm{P}$, phosphorus; TDN, total digestible nutrients.

\section{Introduction}

Leafy spurge is a deep-rooted, herbaceous, perennial weed estimated to infest over 1 million ha in 26 states and six Canadian provinces (Dunn 1979). In North Dakota, leafy spurge occupies approximately $1 / 2$ million ha or over $9 \%$ of the untilled land (North Dakota Department of Agriculture 1991). Leafy spurge was estimated to reduce the livestock carrying capacity in North Dakota by 77,000 cows, resulting in an annual direct net income loss of \$23 million (Leistritz et al. 1992).

Previous research has shown that cattle partially or totally avoided leafy spurge-infested sites (Lym and Kirby 1987). Goats, however, consume and possibly prefer leafy spurge as a dietary constituent (Fay et al. 1989; Walker et al. 1994). The preference for leafy spurge by goats grazing diverse Northern Plains prairie is not documented. The objectives of this study were to analyze botanical and nutritional composition of diets from herded Angora goats on Northern Plains rangeland infested with leafy spurge.

\section{Materials and methods}

The study was conducted on the Sheyenne National Grasslands of the Custer National Forest in Ransom County, approximately $30 \mathrm{~km}$ east and $3 \mathrm{~km}$ north of Lisbon, ND. The Grasslands are also known as the Sandhills, which are part of the Sheyenne Delta of glacial Lake Agassiz.

Average precipitation for the area is $51 \mathrm{~cm}$, with $80 \%$ received during April through September. The long-term average monthly temperatures for the grazing period of May through October range from $22^{\circ} \mathrm{C}$ to $6^{\circ} \mathrm{C}$. The soils within the study area were formed in wind-sorted fine sands. They are deep, excessively drained, and nearly level to hilly soils on low hummocks and hills. Permeability is rapid, and the available water capacity is low. Soils are too sandy for cultivation due to low organic matter content and low fertility. This land is highly susceptible to wind erosion, and a permanent vegetative cover is necessary to prevent soil blowing.

The Grasslands are noted for a diversity of plant species (Seiler and Barker 1985). Various cool- and warm-season grasses, grasslike plants, forbs, shrubs, and trees are present. Plant names follow the Flora of the Great Plains (Great Plains Flora Association 1986). Heavy infestations of leafy spurge also occur within the study area. Many of the wooded areas have never received herbicide application, favoring the expansion of the leafy spurge infestation.

Leafy spurge was grazed for two consecutive years. Grazing was initiated in early May 1991, using 1,600 Angora goats. The goats were rotated twice through four grazing 
allotments. Grazing terminated October 3, 1991. In 1992, the rotation of goats was similar, but involved two herds of 1,300 each. The goats were concentrated on areas of heavy leafy spurge infestations each morning and evening and allowed to freely graze for 2 to 3 hours. Following a grazing period, the herder would relocate and return the goats to camp. Cattle were present in all of the allotments and were rotated according to Forest Service grazing agreements.

Botanical composition of diets was determined by gathering fresh fecal samples from four to six goats (one sample). Five samples were taken $4 \mathrm{~d}$ in a row. Diet collection periods were early and mid-June, mid-July, early August, and mid-September each year. Fecal samples were oven-dried at $60^{\circ} \mathrm{C}$ and ground through a 1-mm screen in a Wiley mill, with microhistological analysis determined. ${ }^{3}$

Available forage was measured by clipping all standing biomass in a $0.1-\mathrm{m}^{2}$ quadrat, separating to plant classes, oven drying at $60^{\circ} \mathrm{C}$, and weighing. Fifteen quadrats were randomly sampled in each of five general cover types on each allotment in early and mid-June, mid-July, early August, and mid-September. These cover types were chosen, based on the dominant species and related topography of that particular area. They were Poa, Poa-Euphorbia, Koeleria-Stipa, Koeleria-Stipa-Euphorbia, and Populus-Euphorbia. The acreage of each cover type was determined using a planimeter. Total available forage was calculated for each allotment.

Relative preference ratings were determined by comparing seasonally available forage to ingested forage within allotment as determined by fecal analysis, using the formula:

$$
\text { Relative preference }=\frac{\% \text { in diet }-\% \text { available }}{\% \text { in diet }+\% \text { available }}
$$

A relative preference of 0 would indicate selection of a species or plant in accordance with its availability. Values greater than 0 indicate preference for, while values less than 0 indicate avoidance.

Dietary samples collected for nutrient analyses began by videotaping eight goats over two morning grazing periods ( 3 to $4 \mathrm{~h}$ ) during each seasonal collection period with a VHS camcorder. After viewing the video, four diets were plucked on $2 \mathrm{~d}$ to reflect what the goats had selected. The samples were oven-dried at $60 \mathrm{C}$, ground through a 1-mm screen in a Wiley mill, and evaluated for crude protein $(\mathrm{CP})$, in vitro dry matter digestibility (IVDMD), and phosphorus (P). Crude protein was determined using the Kjeltec Auto System II. ${ }^{4}$ In vitro dry matter digestibility was determined using a modified procedure of Tilley and Terry (1963). Standard forages of known in vivo digestibilities were included in each in vitro digestion trial to correct IVDMD to apparent digestibility. Phos-

\footnotetext{
${ }^{3}$ Composition Analysis Laboratory, Ft. Collins, CO 80524.

${ }^{4}$ Tecator Co., Hoganas. Sweden.
} 
phorus was determined with vanadatemolybdate yellow color development measured with a Spectronic $20 .^{5}$

\section{Results and discussion}

Leafy spurge and Kentucky bluegrass (Poa pratensis L.) were the dominant species available for grazing in the allotments (Table 1). Together, they comprised between 44 and $69 \%$ of available seasonal forage. Warm-season grasses and other broad-leaved plants, forbs, shrubs, and trees were minor components of available seasonal forage.

Table 1. Standing crop ( $\mathrm{kg} / \mathrm{ha}$ ) and composition $(\%)^{\mathrm{a}}$ of vegetation in the study area of the Sheyenne National Grasslands, ND, averaged across 2 yr (1991-1992).

\begin{tabular}{|c|c|c|c|c|c|c|c|c|c|c|}
\hline \multirow[t]{2}{*}{ Component } & \multicolumn{2}{|c|}{ Early June } & \multicolumn{2}{|c|}{ Mid-June } & \multicolumn{2}{|c|}{ Mid-July } & \multicolumn{2}{|c|}{ Early August } & \multicolumn{2}{|c|}{$\begin{array}{c}\text { Mid- } \\
\text { September }\end{array}$} \\
\hline & $\mathrm{kg} / \mathrm{ha}$ & $\%$ & $\mathrm{~kg} / \mathrm{ha}$ & $\%$ & $\mathrm{~kg} / \mathrm{ha}$ & $\%$ & $\mathrm{~kg} / \mathrm{ha}$ & $\%$ & $\mathrm{~kg} / \mathrm{ha}$ & $\%$ \\
\hline $\begin{array}{l}\text { Kentucky blue- } \\
\text { grass }\end{array}$ & 341 & 26 & 862 & 42 & 461 & 25 & 299 & 22 & 307 & 26 \\
\hline $\begin{array}{l}\text { Other cool-season } \\
\text { grasses }\end{array}$ & 297 & 23 & 332 & 16 & 302 & 16 & 116 & 9 & 197 & 16 \\
\hline $\begin{array}{l}\text { Warm-season } \\
\text { grasses }\end{array}$ & 52 & 4 & 84 & 4 & 241 & 13 & 101 & 8 & 222 & 19 \\
\hline Grasslike plants & 204 & 16 & 100 & 5 & 263 & 14 & 204 & 15 & 100 & 8 \\
\hline Leafy spurge & 308 & 24 & 644 & 27 & 340 & 19 & 320 & 24 & 341 & 29 \\
\hline Forbs & 50 & 4 & 56 & 3 & 161 & 9 & 100 & 7 & 16 & 1 \\
\hline Shrubs and trees & 44 & 3 & 54 & 3 & 71 & 4 & 204 & 15 & 8 & 1 \\
\hline $\begin{array}{l}\text { Total standing } \\
\text { crop }\end{array}$ & 1,296 & 100 & 2,132 & 100 & 1,839 & 100 & 1,344 & 100 & 1,191 & 100 \\
\hline
\end{tabular}

Goats readily selected leafy spurge in all seasons (Table 2). Leafy spurge comprised between 22 and $66 \%$ of the seasonal diets and exceeded $40 \%$ in over half of the collection periods over the $2 \mathrm{yr}$. Warm-season grasses, and the shrub and tree component were also consistently selected by goats in seasonal diet sampling. Kentucky bluegrass, the dominant graminoid in the study pastures, never totaled $1 \%$ of seasonal goat diets during the study.

Several differences in diet selectivity were evident between years (Table 2). Leafy spurge selection was greater in the later sample periods in 1992. Seasonal utilization of shrubs and trees by the goats was more uniform in 1991, while seasonal use of warm-season grasses was more uniform in 1992. Goats selected cool-season grasses, other than Kentucky bluegrass, readily throughout June in 1992 but only in the last half

\footnotetext{
${ }^{5}$ Bausch and Lomb. 820 Linden Ave., Rochester, NY 14625.
} 
Table 2. Mean relative density (\% \pm the SE) of leafy spurge and plant classes in Angora goat diets as determined by microhistological fecal analysis.

\begin{tabular}{|c|c|c|c|c|c|}
\hline Forage class & Early June & Mid-June & Mid-July & Early August & Mid-September \\
\hline & \multicolumn{5}{|c|}{1991} \\
\hline Kentucky bluegrass & $0.1 \pm 0.03$ & $0.1 \pm 0.04$ & $0.1 \pm 0.03$ & $0.1 \pm 0.06$ & $0.4 \pm 0.10$ \\
\hline $\begin{array}{l}\text { Other cool-season } \\
\text { grasses }\end{array}$ & $5.2 \pm 0.77$ & $31.8 \pm 3.39$ & $0.5 \pm 0.13$ & $2.4 \pm 0.48$ & $9.2 \pm 1.86$ \\
\hline Warm-season grasses & $20.3 \pm 2.13$ & $4.2 \pm 0.75$ & $7.3 \pm 1.30$ & $30.7 \pm 2.47$ & $10.7 \pm 1.04$ \\
\hline Grasslike plants & $6.8 \pm 0.90$ & $3.7 \pm 0.51$ & $1.1 \pm 0.30$ & $4.2 \pm 0.77$ & $8.4 \pm 1.19$ \\
\hline Leafy spurge & $34.4 \pm 1.55$ & $41.2 \pm 2.47$ & $48.9 \pm 1.94$ & $38.9 \pm 2.71$ & $43.6 \pm 3.10$ \\
\hline Forbs & $0.4 \pm 0.10$ & $1.1 \pm 0.23$ & $3.2 \pm 0.06$ & $2.9 \pm 0.62$ & $4.0 \pm 0.60$ \\
\hline \multirow[t]{2}{*}{ Shrubs and trees } & $32.9 \pm 2.77$ & $17.9 \pm 1.67$ & $40.9 \pm 1.50$ & $20.8 \pm 2.79$ & $23.7 \pm 1.51$ \\
\hline & \multicolumn{5}{|c|}{1992} \\
\hline Kentucky bluegrass & $0.2 \pm 0.09$ & $0.0 \pm 0.0$ & $0.0 \pm 0.0$ & $0.0 \pm 0.0$ & $0.0 \pm 0.0$ \\
\hline $\begin{array}{l}\text { Other cool-season } \\
\text { grasses }\end{array}$ & $32.5 \pm 3.45$ & $14.9 \pm 2.00$ & $3.2 \pm 0.74$ & $0.9 \pm 0.23$ & $1.8 \pm 0.53$ \\
\hline Warm-season grasses & $17.4 \pm 2.01$ & $17.6 \pm 2.97$ & $18.2 \pm 1.66$ & $23.4 \pm 2.91$ & $14.1 \pm 1.44$ \\
\hline Grasslike plants & $8.7 \pm 1.53$ & $5.9 \pm 1.04$ & $3.0 \pm 0.43$ & $6.7 \pm 0.94$ & $3.0 \pm 0.66$ \\
\hline Leafy spurge & $21.5 \pm 1.63$ & $56.7 \pm 5.24$ & $55.2 \pm 2.42$ & $58.3 \pm 3.58$ & $65.5 \pm 2.11$ \\
\hline Forbs & $0.4 \pm 0.12$ & $0.3 \pm 0.16$ & $0.3 \pm 0.10$ & $0.5 \pm 0.14$ & $0.6 \pm 0.17$ \\
\hline Shrubs and trees & $19.3 \pm 2.9$ & $4.4 \pm 1.29$ & $20.1 \pm 2.33$ & $10.2 \pm 1.0$ & $15.0 \pm 1.04$ \\
\hline
\end{tabular}

of June in 1991. Predominant cool-season grasses selected were western wheatgrass $(\mathrm{Ag}$ ropyron smithii Rydb.), smooth brome (Bromus inermis L.), and needlegrasses (Stipa spp.). Forbs, other than leafy spurge, and grasslike plants (Carex spp.) were selected in small amounts both years. Major forbs selected were fringed sage (Artemisia frigida Willd.), mustards (Brassica spp.), wild buckwheats (Eriogonum spp.), yellow sweet clover (Melilotus officinalis (L.) Pall.], and shrubby cinquefoil (Potentilla fruiticosa L.).

Leafy spurge was preferred throughout both years (Table 3). Herding may have influenced this preference despite the goats always having an abundant variety of forage species to select from. Goats also preferred shrubs throughout seasonal diet collections. Shrub selection included Saskatoon serviceberry (Amelanchier alnifolia L.), lead plant (Amorpha canescens Pursh.), silverberry (Eleagnus commutata Bernh.), oaks (Quercus spp.), sumac (Rhus spp.), rose (Rosaceae spp.), willow (Salix spp.), and western snowberry (Symphoricarpos occidentalis Hook). A preference for shrubs and trees was also evident by browse lines that were common around camps where goats had access to aspen (Populus tremuloides Michx.), chokecherry (Prunus virginiana L.), and willow (Salix spp.).

A dominant plant species in the grazing allotments was Kentucky bluegrass. The goats avoided this species at all times of the year, as indicated by the highly negative preference values. Warm-season grasses were seasonally preferred, especially early in the 
Table 3. Relative preference index ${ }^{a}$ for forage selected by Angora goats.

\begin{tabular}{lccccc}
\hline \multicolumn{1}{c}{ Forage class } & Early June & Mid-June & Mid-July & Early August & Mid-September \\
\cline { 2 - 6 } Kentucky bluegrass & -10 & -10 & -10 & -10 & -10 \\
Other cool-season grasses & -6 & 3 & -9 & -8 & -8 \\
Warm-season grasses & 7 & 0 & -2 & 4 & -3 \\
Grasslike plants & -4 & -1 & -6 & -5 & -9 \\
Leafy spurge & 2 & 4 & 0 & 4 & 3 \\
Forbs & -8 & -4 & 7 & -5 & -5 \\
Shrubs and trees & 8 & 7 & 8 & 7 & 5 \\
& & & 1992 & & -10 \\
Kentucky bluegrass & -10 & -10 & -10 & -10 & -8 \\
Other cool-season grasses & 2 & 0 & -4 & -9 & -1 \\
Warm-season grasses & 6 & 6 & 3 & 3 & -5 \\
Grasslike plants & -3 & 1 & -2 & -4 & 4 \\
Leafy spurge & 0 & 4 & 1 & 5 & -3 \\
Forbs & -7 & -8 & 4 & -9 & 9 \\
Shrubs and trees & 7 & 2 & 5 & 4 & \\
\hline${ }^{a} 0=$ selection in accordance with availability; $>0=$ preference for plant class; $<0=$ nonpreference or \\
\end{tabular}

growing season. The predominant warm-season grass selected was sand dropseed [Sporobolus cryptandrus (Torr.) Gray]. Others selected were grama grasses (Bouteloua spp.), bluestems (Andropogon spp.), and switchgrass (Panicum virgatum L.).

Cattle are the preferred livestock of producers in southeastern North Dakota. These producers were concerned that Angora goats co-inhabiting leafy spurge-infested rangeland with cattle might compete for the graminoid forages. Cattle avoid leafy spurge in diet selection in this area and utilize over $60 \%$ of the annual available cool- and warm-season grass production (Lym and Kirby 1987). Cattle were even observed to partially or totally avoid leafy spurge-infested sites while grazing. Angora goat seasonal diet selection is dominated by broad-leaved plant species such as leafy spurge, shrubs, and trees, which is consistent with other reports (Olsen and Hansen 1977; Sedivec and Maine 1993; Walker and Kronberg 1992; Walker et al. 1994). Angora goats also preferred warm-season grasses in the early grazing season. Utilization of these grasses should be monitored in pastures cograzed by cattle and goats to prevent potential overuse. Otherwise, Angora goats appear to be complementary grazers with cattle on leafy spurge-infested Northern Plains rangeland.

The nutritional composition of seasonal goat diets remained high throughout the grazing season (Figure 1). The high quality in diets selected by the goats may be explained by the predominance of leafy spurge in these diets. The nutritional value of leafy spurge has been reported to be comparable to alfalfa (Medicago sativa L.) (Fox et al. 1991). Diets in 1991 exhibited a higher plane of nutrition than did diets in 1992. Greater vegetative growth was produced by more favorable weather conditions in 1992, which may have diluted nutrient density in forage selected by the goats. In vitro dry matter digestibility 
declined in diets seasonally until fall, when lush regrowth of leafy spurge was available. Crude protein and phosphorus generally declined in goat diets as the grazing season progressed.

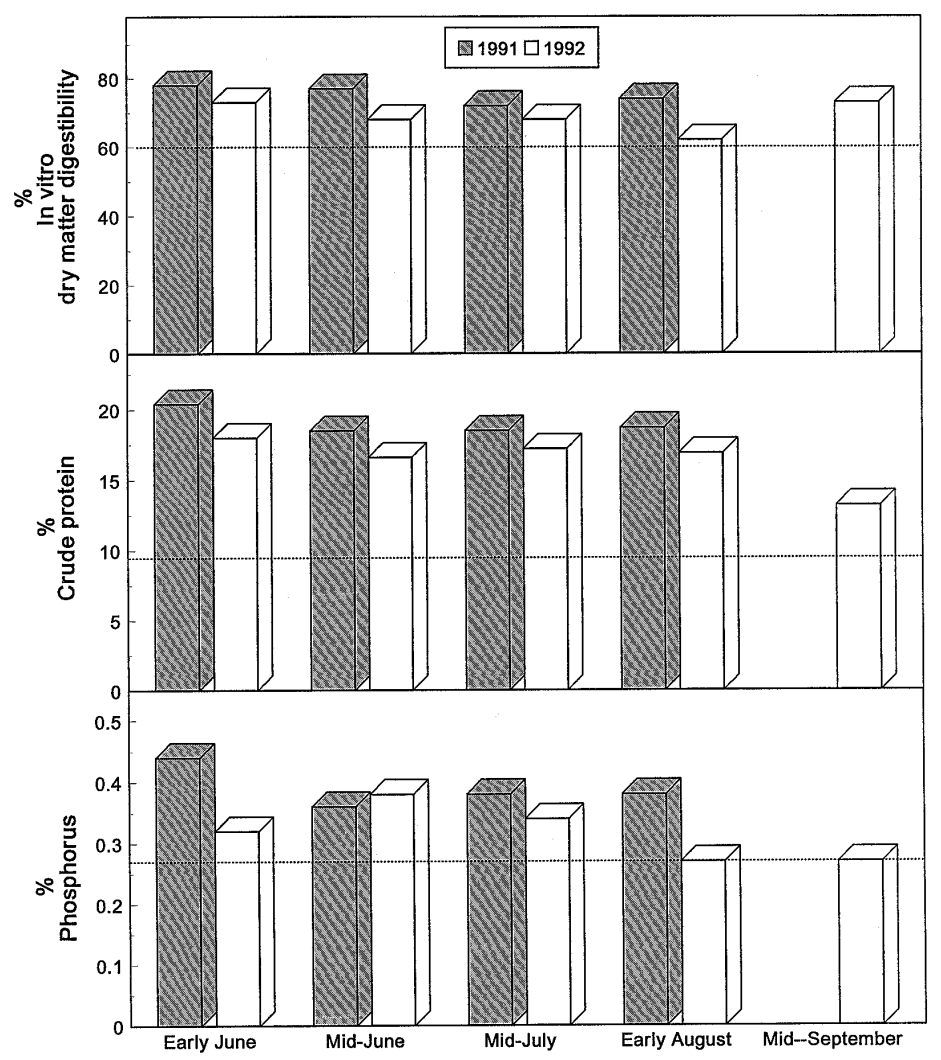

Figure 1. Composition of goat diets grazing leafy spurge-infested rangeland and the nutritional requirements of a 60-kg nursing doe (dashed line).

The nutritional requirements of a high-producing 60-kg Angora goat doe nursing twins at a $4.5 \%$ milk fat level with an intake of $3.5 \%$ of body weight are $60 \%$ total digestible nutrients (TDN) (or IVDMD as analyzed and corrected in this study), 9.7\% CP, and $0.27 \% \mathrm{P}$ (National Research Council 1981). These requirements were met or exceeded in all seasonal diet collections both years. Leafy spurge-based diets should promote Angora goat growth and production throughout the grazing season in the Northern Plains.

Goats have long been utilized for weed (Radcliffe 1985; Sakanooue et al. 1995) and brush (Adams and Hughes 1977; Merrill and Taylor 1976) management. Dietary preferences indicate that Angora goats also offer Northern Plains land managers a tool to biologically manage leafy spurge infestations. Goats should also be compatible in an integrated pro 'gram with herbicides, insects, or fire in managing leafy spurge. Their greatest utility may be in rough or sensitive environments such as woodlands, waterways, and subirrigated range sites, where herbicides cannot be or are not easily used in leafy spurge management and where protection of shrubs and trees is not a priority. 


\section{Acknowledgments}

The authors thank Kelly Krabbenhoft, Larry Potts, and Dale Siebert for their assistance. This work was funded in part by USDA-APHIS, USDA Forest Service, North Dakota State Agricultural Experiment Station, and the North Dakota Cooperative Extension Service.

\section{Literature cited}

Adams, T. E. and C. L. Hughes. 1977. Want biological brush control? Try goats! Rangeman's J. 4:4.

Dunn, P H. 1979. The distribution of leafy spurge and other Euphorbia spp. in the United States. Weed Sci. 27:509-516.

Fay, P. K., V. T. McElligott, and K. M. Havstad. 1989. Containment of freeranging goats using pulse-radio-wave-activated shock collars. Appl. Anim. Behav. Sci. 23:165-171.

Fox, D. A., D. R. Kirby, R. G. Lym, J. S. Caton, and K. D. Krabbenhoft. 1991. Chemical composition of leafy spurge and alfalfa. N. D. Farm Re,. 48:7-9.

Great Plains Flora Association. 1986. Flora of the Great Plains. Lawrence, KS: University Press of Kansas. $1392 \mathrm{p}$.

Leistritz, F. L., F. Thompson, and J. A. Leitch. 1992. Economic impact of leafy spurge (Euphorbia esula) in North Dakota. Weed Sci. 32:348-352.

Lym, R. G. and D. R. Kirby. 1987. Cattle foraging behavior in leafy spurge (Euphorbia esula L.) infested rangeland. Weed Technol. 1:314-318.

Merrill, L. B. and C. A. Taylor. 1976. Take note of the versatile goat. Rangeman's J. 3:74-76.

National Research Council. 1981. Nutrient requirements of goats in temperate and tropical countries. Washington, DC: National Academy Press. 91 p.

North Dakota Department of Agriculture. 1991. Weed Control Survey by County. Bismarck, ND: North Dakota Department of Agriculture. $36 \mathrm{p}$.

Olsen, F W. and R. M. Hansen. 1977. Food relations of wild free-roaming horses to livestock and big game on Red Desert of Wyoming. J. Range Manage. 30:17-20.

Radcliffe, J. E. 1985. Grazing management of goats and sheep for gorse control. N. Z. J. Exp. Agric. 13:181-190.

Sakanoouc, S., N. Kitahara, and H. Hayashi. 1995. Biological control of Rumen obiusifolius L. by goat grazing. Jpn. Agric. Res. Q. 29:39-42.

Sedivec, K. K. and R. P. Maine. 1993. Angora goat grazing as a biological control for leafy spurge: a three-year summary. In Proceedings of the Leafy Spurge Symposium. Fort Collins. CO: Colorado State University. pp. 1-5.

Seiler., G. J. and W. T. Barker. 1985. Vascular flora of Ransom. Richland and Sargent counties, North Dakota. Prairie Nat. 17:193-240.

Tilley, J.M.A. and R. A. Terry. 1963. A two-stage technique for the in vitro digestion of forage crops. J. Br. Grassl. Soc. 18: 104-111.

Walker. J. and S. Kronberg. 1992. Managing leafy spurge with livestock. In R. A. Masters, S. J. Nissen, and G. Friisoe, eds. Proceedings of the Leafy Spurge Symposium. Lincoln. NE: University of Nebraska. pp. 23-28.

Walker, J. W., S. L. Kronberg, S. L. Al-Rowaily, and N. E. West. 1994. Comparison of sheep and goat preferences for leafy spurge. J. Range Manage. 47:429-434.

Page 8 of 8 